\title{
Status of Exotic Flora in Kashmir Valley
}

Nasir Rashid Wani and Shah Murtaza Mushtaq

Faculty of Forestry, Sher-e-Kashmir University of Agricultural Sciences and Technology of Kashmir, Shalimar (J E K) India, 191121, India

\begin{abstract}
The Kashmir Himalaya, known for its indigenous and endemic flora, also provides home to a large number of exotic plants, which exhibit a wide taxonomical and distributional stretch. Although, some preliminary studies have been carried out in the region on some aspects of its exotic flora, the inventorization and documentation of its exotic have received a little or negligible attention. There is a lot of scope of these exotic plant species in Kashmir valley, but lack of authentic identification has been as a big hurdle in their scientific management. It is in this backdrop that the present floristic study was carried out to identify, inventorize, document and characterize the exotic plant species grown in the Valley. The present study has revealed that Kashmir Valley grows 317 exotic plant species, which belong to 209 genera in 85 families. Dicotyledons are the largest group, represented by 252 species in 163 genera and 67 families. Monocotyledons comprise 52 species in 37 genera and 13 families. Gymnosperms are the smallest group, with 13 species distributed in 9 genera and 5 families. Asteraceae is the largest family containing 33 exotic species.
\end{abstract}

Key Words: exotic plants, flora, Kashmir

\section{Introduction}

Nature has nurtured man in its lap since its existence. Food, shelter and clothing were primary gifts which nature bestowed to the baby of mankind. With its development the horizontal and vertical needs which time challenged were also bestowed by nursing nature. Man landed on the zenith of development which include cultural, economic, political, social and wide array of other developments utilizing the fuel injected by nature in his inner. Cracking the contribution of nature into components, plants rank first. The plants served man with many purposes besides providing the basic life support system of food, shelter, and clothing.

The term alien exotic refer to species which are non-native species of the area but they arrived in an area outside their natural range. They established themselves in an area, exponentially increasing their population, thus out compet- ing the native species of that area and usually bringing change in ecosystem functions. A large part of the problem comes in declaring what qualifies a plant as an invasive species. No universal definition has been established. However, some general characteristics have been considered by researchers. Human induced disturbances include the removal of native vegetation for activities such as farming, forestry and mining. These provide an open niche for alien invasiveness due to lack of competition and altered soil structure, availability of moisture and nutrients (Thompson et al. 1995).

The Valley of Kashmir is ranked as paradise on earth. It provides home to a large number of plant and animal species (Lambert 1933; Naqshi et al. 1976; Singh and Kachroo 1983; Dar et al. 2002). This hospitable approach is not only restricted to native species but to exotics as well (Singh and Misri 1974; Ara et al. 1995; Dar et al. 1995, 2002).

Received: January 21, 2012. Revised: February 23, 2012. Accepted: February 24, 2012. 
The valley hosts a large number of exotic plant species showing wide taxonomic diversity (Stewart 1972; Ara et al. 1995; Dar et al. 1995, 2002; Khuroo et al. 2007). The economy of valley is agriculture based economy (John et al. 2007).

Exotics grown in Kashmir show better performance in both quality and quantity attributes as compared to other regions of India (John et al. 1996, 2007). The cut flowers, essential oils, bulbs etc. witness huge production compared to other regions of India (John et al. 1996). The industry has a lot of scope to generate revenue and change fortunes of masses. There is no documentation of exotic growing in Kashmir valley. The authentic identification and documentation of exotic has been perceived as a hurdle for speedy growth of floriculture industry (John et al. 1996). Besides, the economy of state being agriculture based, demands that exotic invasives be first documented and then kept under constant monitoring as invasive species are known for causing tremendous economic losses in agricultural productivity (John et al. 1996; Khuroo et al. 2007). Exotic alien invasive species are also notoriously known for eroding native species richness and driving species to extinction (Pysek 1998; Pysek et al. 2002, 2004). Exotic invasive species are categorized as threat to native species diversity, as the former displace the latter. It is in this backdrop that why the present study of exploration, authentic exotic flora was carried out.

\section{Materials and Methods}

\section{Exploration}

Although all places dwelling exotic were scanned and the diversity were assessed, the places harboring maximum diversity were selected have the main collection and study sites. The exploration was carried out in every nook and corner of Kashmir valley India. The whole flora was scanned for screening exotics. The main sites which were surveyed include:

1. Tulip garden.

2. Nehru Memorial Botanical Garden, Cheshmashahi.

3. Nishat Garden.

4. Shalimar Garden.

5. Harwan Garden.

6. Govt.Arts Emporium Garden
7. Hazratbal Park.

8. Kashmir University Botanical Garden.

9. Kokernag

10. Achabal

11. Pahalgam

12. Nurseries/roadside plant vendors.

13. Private lawns.

\section{Collection and identification}

The exotic plants were collected and then identified to species level using available literature. The voucher specimens of all collected and identified species have been deposited in faculty of forestry, SKUAST-K. The whole information regarding their taxonomic affinity, taxonomic dispersion, local distribution, native origin and abundance has been compiled in the form of a data base.

\section{Results and Discussion}

The introduction of exotic species can be done deliberately by natural resource managers, most often to increase commercial production in agriculture and forestry. In countries such as South Africa, Chile, Taiwan, Australia, Sweden and Finland, a majority of commercially planted tree species are introduced. This has resulted in higher production of woody biomass that would otherwise have been possible using only native tree species. The present study revealed that the paradise is housing 317 exotic species beautifying its corridors and corners. These 317 alien species were found to be dispersed in 209 genera and 85 families (Fig. 1). Dicotyledons as usual turned out to be the largest group represented by 252 species, 163 genera, and 67 families. Monocots in the region comprised of 52 species, 37 genera, and 13 families. Gymnosperms were found to be the smallest group with 13 species distributed in 9 genera and 5 families (Fig. 2). The family Asteraceae proved to be the largest family hosting 33 exotic species (Table 1) and genus Prunus were the largest genus with 8 species (Table 2). The habit analysis of exotic flora revealed that herbs comprise of 156 species while as shrubs consisted of 95 species with 66 species of trees (Fig. 3).

The Valley of Kashmir is witnessing continuous introduction of exotic plant and animal species owing to globalization which has condensed the world into a global 


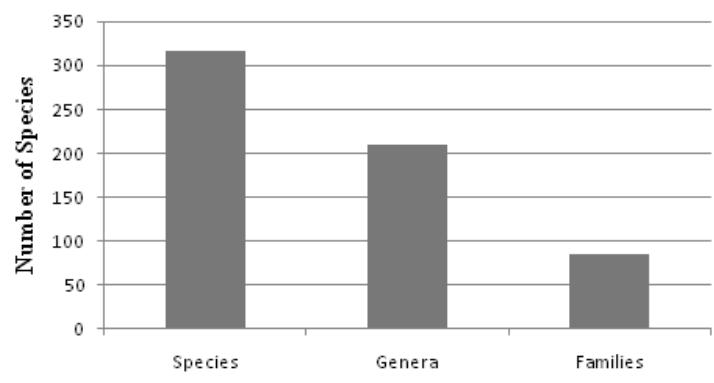

Fig. 1. Exotic flora of Kashmir valley.

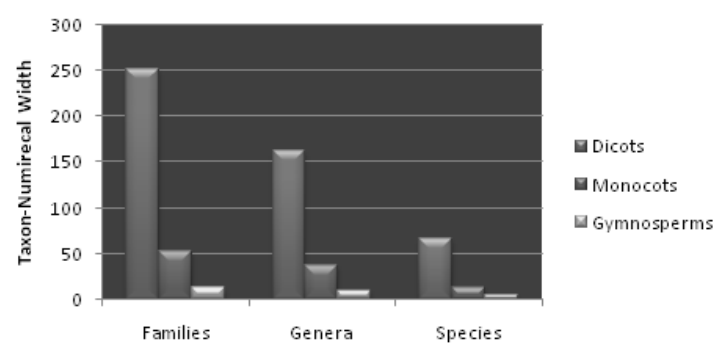

Fig. 2. Taxanomic dispersion of exotic flora of Kashmir valley.

Table 1. Top ten families in terms of percentage of exotic species

\begin{tabular}{clc}
\hline S. No & Family & Percentage of species \\
\hline 1. & Asteraceae & $10.41 \%$ \\
2. & Rosaceae & $7.25 \%$ \\
3. & Liliaceae & $4.73 \%$ \\
4. & Oleaceae & $4.10 \%$ \\
5. & Caryophyllaceae & $3.47 \%$ \\
6. & Amaryllidaceae & $3.15 \%$ \\
7. & Salicaceae & $3.15 \%$ \\
8. & Iridaceae & $3.15 \%$ \\
9. & Leguminosae & $3.15 \%$ \\
10. & Ranunculaceae & $2.52 \%$ \\
\hline
\end{tabular}

village. The high-tech cross border transport and migration of humans has provided easy pathway to plant species to witness a wide spread on the world map. Our present study on the exotic flora elucidates and reveals that horticulture is the main pathway which invites and accumulates exotics in this part of Himalaya (Khuroo et al. 2007). The present study is so far the major floristic study on exotics of the valley which documents 317 exotic plant species, most of them reported for the first time from the valley. The study reveals that the species which are highly ranked in the international market show better degree of occurrence and performance
Table 2. Top ten genera with maximum number of species

\begin{tabular}{clc}
\hline S. No & \multicolumn{1}{c}{ Genus } & Number of species \\
\hline 1. & Prunus & 8 \\
2. & Salix & 7 \\
3. & Ligustrum & 6 \\
4. & Magnolia & 5 \\
5. & Iris & 5 \\
6. & Rosa & 5 \\
7. & Dianthus & 5 \\
8. & Amaranthus & 4 \\
9. & Lilium & 4 \\
10. & Narcissus & 3 \\
\hline
\end{tabular}

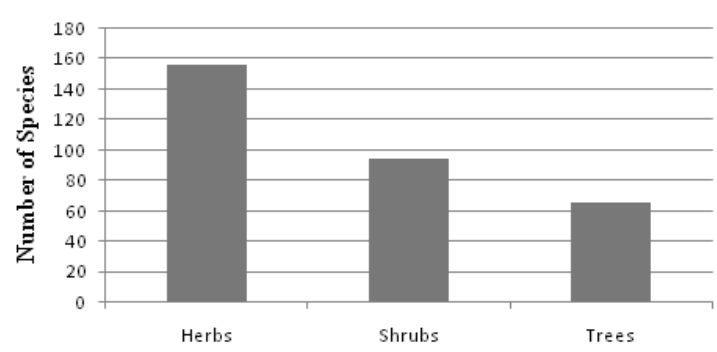

Fig. 3. Textural fragmentation of exotic flora of Kashmir valley.

in terms of yield viz; flower size, flower number, bulb production, bulb size, herbage and oil content in the valley. This argument is well supported by various other studies in relation to it (John et al. 2007). These tree species could prove handy in meeting the increasing demands of a rapidly growing human population and will help to alleviate shortages in timber, fodder and fuel wood. Prominent tree species include Salix and poplar planted on farmlands and irrigated plantations.

The present inventory of exotic plant species growing in Kashmir valley will be of great utility for the socio-economic development of the state which is in conformity to the findings of (Singh and Kachroo 1983). The inventory will serve as a data base for further studies. The valuable species with international market have been provided with authentic identification and characterization. The data base provides a baseline for further research on exotic flora in general and exotics in particular.

Biological invasions by alien species are widely recognized as a significant component of human-caused global environmental change. Invasive alien plant species may 
profoundly alter ecosystem structure, resulting in significant losses in the economy and in the biological diversity and function of invaded ecosystems and thus are of great concern to both ecologists and economists (Elton 1958; Lonsdale 1999; Pimentel et al. 2000; Meyerson and Mooney 2007).

However, the present documentary also finds tremendous significance as a data base for the stake holders for monitoring and managing exotic invasive species which cause tremendous loss to crops and economy. Besides, the inventory will be of great help to conservation biologists for ranking threats to native flora.

\section{Conclusions}

To bring more area under tree cover, there is need of introduction of fast growing exotic species. Exotics supplement indigenous species to increase quality and quantity of forest products. Exotic species are used to reduce deforestation and land degradation, as they are more productive than indigenous species. In many parts of the tropics there is no option except to use exotic species because indigenous species do not perform well. The need for introduction of exotic species arises either because the native flora is either scanty or is chiefly composed of species which are extremely slow growing and not readily available for use. Exotics are the only way to avoid the shortage of desired products in the near future. At last when planting exotic species, the selection of correct species and provenances through testing is an important initial step.

\section{References}

Ara S, Naqshi AR, Baba MY. 1995. Indigenous and Exotic Trees and Shrubs of Kashmir Valley. Indian J Forestry 8: 233-272.

Dar GH, Naqshi AR, Ara S. 1995. New Records and New Taxa of Flowering Plants from Jammu \& Kashmir State. Oriental Sci
(Spl Publ), Bhopal, India.

Dar GH, Bhagat RC, Khan MA. 2002. Biodiversity of the Kashmir Himalaya. Valley Book House Hazratbal, Srinagar.

Elton CS. 1958. The Ecology of Invasions by Animals and Plants, Kluwer Academic Publishers, Methuen, London.

John AQ, Bichoo GA, Siddique MA. 1996. Performance of Gladiolus Cultivars in Kashmir. Flora and Fauna Jhansi 2: 75-77.

John AQ, Rather ZA, Paul TM, Neelofer A. 2007. Evaluation of Ornamental Bulbous Plants for Landscaping in Temperate Regions. Journal of Ornamental Horticulture 10: 1-8.

Khuroo AA, Irfan R, Reshi Z,Wafai BA. 2007. The Alien Flora of Kashmir Himalayas. Biological Invasions 9: 269-292.

Lambert WJ. 1993. List of Trees and Shrubs for Jammu and Kashmir Forest Circles. Bot Ser For Bull 80: 56-68.

Lonsdale WM. 1999. Global Patterns of Plant Invasions and the Concept of Invisibility. Ecology 80: 1522-1536.

Meyerson LA, Mooney HA. 2007. Invasive Alien Species in an era of Globalization. Frontiers in Ecology and the Environment 5: 199-208.

Naqshi AR, Javeed GN. 1976. Two New Plant Records for India. J Bombay Nat Hist Soc 74: 393-394.

Pyšek P. 1998B. Is There a Taxonomic Pattern to Plant Invasion? Oikos 82: 282-294.

Pimentel D, Lach L, Zuniga R, Morrison D. 2000. Environmental and Economic Costs of Non indigenous Species in the United States. Bioscience 50: 53-65.

Pysek P, Sadlo J, Mandak B. 2002. Catalogue of Alien Plants of Czech Republic. Preslia Praha 74: 97-186.

Pysek P, Richardson DM, Rajmanek M, Webster GL, Williamson M, Kirschner J. 2004. Alien Plants in Checklists and Flora: Towards Better Communication between Taxonomists and Ecologists. Taxon 53: 131-143.

Singh JB, Kachroo P. 1983. Exotic Trees and Shrubs of Kashmir. Ind Forester 109: 60-76.

Singh G, Misri B. 1974. Some Exotic Ornamentals of Kashmir. Indian J Hort 31: 91-94.

Stewart RR. 1972. An Annotated Catalogue of the Vascular plants of West Pakistan and Kashmir. In: Flora of West Pakistan (Nasir E, Ali SI, eds). Fakhri Press, Karachi, pp 1-1028.

Thompson K, Hodgson JD, Rich TCG. 1995. Native and Alien Invasive Plants: More of the Same? Ecography 18: 390-402.

Zeerak NA, Wani SA. 2007. Diversity of Irises from Kashmir Himalaya. Journal of Ornamental Horticulture 10: 115-118. 